\title{
Scrophularia longiflora Benth. and S. nana Stiefelh. (Scrophulariaceae), two distinct species from Iran, confused under the name S. farinosa Boiss.
}

\author{
Massoud Ranjbar, Narges Rahchamani \& Laurent Gautier
}

\begin{abstract}
RANJBAR, M., N. RAHCHAMANI \& L. GAUTIER (2016). Scrophularia longiflora Benth. and S. nana Stiefelh. (Scrophulariaceae), two distinct species from Iran, confused under the name S. farinosa Boiss. Candollea 71: 195-203. In English, English abstract. DOI: http://dx.doi.org/10.15553/ c2016v712a5

The authors revise the material associated with Scrophularia farinosa Boiss. (Scrophulariaceae) and its synonyms according to "Flora Iranica". Two distinct taxa emerge, which differ in terms of morphology, anatomy, distribution and ecology and both deserve recognition at species level. Scrophularia longiflora Benth. is an earlier synonym of Scrophularia farinosa, and is reinstated as the valid name for this species based on priority principle. Scrophularia nana Stiefelh. which was synonymized with Scrophularia farinosa, is resurrected as a separate species. We provide a key to differentiate between the two species as well as detailed descriptions with illustrations and a distribution map. Additionally, lectotypes are designated for Scrophularia farinosa and Scrophularia nana.
\end{abstract}

\section{Keywords}

SCROPHULARIACEAE - Scrophularia - Iran - Identification key - Lectotypification - Taxonomy

Addresses of the authors:

MR, NR: Department of Biology, Herbarium division, Bu-Ali Sina University, P.O. Box 65175/4161, Hamedan, Iran. E-mail: ranjbar@basu.ac.ir

LG : Conservatoire et Jardin botaniques de la Ville de Genève and Laboratory of Plant Systematics and Biodiversity, University of Geneva, C.P. 60, 1292 Chambésy, Switzerland. 


\section{Introduction}

The genus Scrophularia L. is one of the largest genera of the family Scrophulariaceae with nearly 200 (MABBERLEY, 1997) to more than 300 species (Willis, 1973). In Iran Scrophularia is a widespread and diversified genus with recent accounts listing ca. 60 species (ATTAR, 2011). However, fieldwork often reveals that the taxonomy and nomenclature of these species still need to be revised.

Recent collections from Iran and a complete revision of material available in herbaria reveal the existence of two morphologically distinct taxa of contrasted distribution and ecology, that both key out as $S$. farinosa Boiss. when using the identification key of Flora Iranica (GRAU, 1981), in which S. longiflora Benth. as well as $S$. nana Stiefelh. are considered as synonyms. In this contribution, we explore the morphological, anatomical and ecological differences between these two taxa, we review the relevant literature and draw the necessary taxonomical and nomenclatural conclusions.

\section{Material and methods}

The present study was based on field observations made in Fars province from 2011 to 2014. In addition, herbarium specimens of Scrophularia deposited at BASU, FAR, and G were examined, as well as digital images of type material at BM, JE, K, $\mathrm{MO}, \mathrm{P}$ and W. We selected a list of characters of importance to the taxonomy of this group including indumentum, leaf shape and variation, shape and size of the corolla tube and position of staminode, and scored their value for the specimens examined.

Anatomical studies were performed on representative specimens of the two taxa deposited at BASU, respectively Ranjbar 35993 and 26927. In order to investigate the indumentum, segments of dried plant specimens such as stems and leaves were separated and preserved in a mixture of water-glycerine-ethanol (1:1:1) for 2 weeks and then washed with distilled water. Transversal sections of the stems were prepared by manual cutting. The sections were cleared with dilute sodium hypochlorite and acetic acid and were then stained with methylene blue and carmine solutions. Then, they were inspected using an Olympus BX-51 photomicroscope at different magnifications and photographed using an Olympus camera.

\section{Results and Discussion}

Examination of herbarium material and anatomical studies clearly allowed us to separate specimens in two taxonomical entities that we hypothesize as distinct species.

The first one includes the type of $S$. longiflora and all type material of $S$. farinosa and we can already conclude that the synonymy proposed by BoIssier (1879) and GraU (1981) is justified, although, as will be explained below, the name that should be used is $S$. longiflora.
The second entity comprises the type material of S. nana. In his revision of the genus Stiefelhagen (1910) described S. nana as new and distinct form S. farinosa (= S. longiflora) not only at a specific level, but attributed these species to separate subsections: S. farinosa in subsect. Farinosae Stiefelh., with a urceolate corolla tube and $S$. nana in subsect. Lucidae Stiefelh., with a ventricose corolla tube. GRAu (1981), when he sunk Scrophularia nana in synonymy, argued that Stiefelhagen had based S. nana on observation of young flowers. However, accumulation of recent material and field observations provide evidence that $S$. nana consistently has a shorter and broader corolla and included stamens, as well as a set of other associated distinct character states.

Table 1 provides the comparison of morphological characters between these two species. Differences in flower structure are also illustrated in Fig. 1.

Details of stems anatomy are illustrated in Fig. 2. Anatomical studies showed slight differences between the stems of S. longiflora and S. nana. In S. longiflora, an outline of the stem transversal section is rather regular and hexagonal, whereas in S. nana is irregular and wrinkled. Both species are covered with trichomes that have a multi-cell base and a cup-shaped head, responsible of the farinaceous appearance of the plants. Although the trichome type is similar in both species, hairs in S. nana are predominantly longer than in S. longiflora and this difference is linked with the number of basic cells of these hairs. By contrast, the hair density in S. longiflora is clearly higher than in S. nana.

On the basis of the results of morphology and anatomy, we conclude that we are in the presence of two clearly distinct taxa, which both deserve specific rank. Distribution and ecology corroborate this conclusion. Both $S$. longiflora and S. nana are limited to Fars province, Iran (Fig. 3A). Scrophularia longiflora is relatively widely distributed there. Although the collection place of its type [Persia] is too vague for mapping, the type collection of its synonym $S$. farinosa comes from Sabz Pushan Mt. which is located in the south west of Shiraz, with its highest point reaching $3167 \mathrm{~m}$. This area experiences a temperate climate with rainfall in winter and a warm and dry summer. $S$. nana is limited to Marvdasht city, north of Shiraz, and its original material comes from a limestone rock near Persepolis and Kotel Parrou. This region, with an altitude about $1620 \mathrm{~m}$, experiences a temperate climate with an abundance of water and suitable soil.

Scrophularia species are known to display a high potential of hybridization. Several other species occur in Fars province, e.g. S. schiraziana Attar \& Hatami, S. denaensis Attar and S. xylobasis Rech. f. It is thus legitimate to ask if S. longiflora or $S$. nana could either be hybrids or if they could have evolved through hybridization. Based on their morphology, it seems unlikely that these species could be potential parents of the two taxa treated in this contribution. However, only 
Table 1. - Morphological features distinguishing Scrophularia longiflora Benth. from S. nana Stiefelh.

\section{S. longiflora}

Leaf phyllotaxy

Lower leaf shape, width [mm], dissection

Lower leaf petiole length $[\mathrm{mm}]$

Upper leaf shape, width [mm], dissection

\section{Mostly alternate}

Broadly ovate, 5-10, pinnatifid to pinnatisect

8-20

Ovate, 4-7, pinnatifid to pinnatisect

\section{S. nana}

Mostly opposite
Broadly ovate to deltoid, 10-17,
entire with serrate to dentate margins
5-12
Broadly ovate to circular to triangular or
rhombic, 10-14, entire with serrate
to dentate margins
5-8
4-5
5-10
1-1.5
lanceolate entire to dentate, 10-15
Ovate-lanceolate, obtuse to acute
Ventricose, purple, 5-7
Included
Reniform
$4-5$

\begin{tabular}{lll} 
Upper petiole length [mm] & $4-10$ & $5-8$ \\
\hline Inflorescence length [cm] & $8-9$ in fruit & $4-5$ \\
\hline Peduncle length [mm] & $4-6$ & $5-10$ \\
\hline Pedicel length [mm] & $1.5-2$ & $1-1.5$ \\
\hline Bract shape, length [mm] & lanceolate, entire to pinnatisect, 5-10 & lanceolate entire to dentate, 10-15 \\
Calyx lobes shape & Ovate-orbicular, obtuse & Ovate-lanceolate, obtuse to acute \\
Corolla shape, colour when fresh, length [mm] & Urceolate, yellowish-white, 9-10 & Ventricose, purple, 5-7 \\
\hline Anthers position & Exserted & Included \\
Staminode shape & Orbiculate & Reniform \\
\hline Style length [mm] & 8 & $4-5$ \\
\hline
\end{tabular}

a molecular study which is beyond the scope of this paper, could definitely rule out such hypothesis. A molecular study would nevertheless be of high interest to elucidate speciation processes of Scrophularia in this region which appears to be a center of diversity for this genus.

\section{Taxonomy}

The two species can be easily separated using the following identification key:

1. Leaves narrowly ovate to broadly ovate, pinnatisected to pinnatipartite; corolla urceolate, 9-10 mm long, yellowishwhite when fresh; stamens exserted, staminode shorter than stamens; style $8 \mathrm{~mm}$ long. S. longiflora

1a. Leaves broadly ovate to circular to triangular or rhombic to deltoid, serrate to dentate; corolla ventricose, $5-7 \mathrm{~mm}$ long, purple when fresh; stamens included, staminode the same length as stamens; style $4-5 \mathrm{~mm}$ long. S. nana

Scrophularia longiflora Benth. in DC., Prodr. 10: 313. 1846 (Fig. 3B-D).

Typus: Iran: Persia, s.d., Anon. s.n. (holo-: G-DC [G00498883]!).

$=$ Scrophularia farinosa Boiss., Diagn. P1. Orient. ser. 1, $7:$ 40. 1846. Lectotypus (designated here): IRAN. Prov. Fars: in fissuris rupium sept. v. spectantium m. Sabst-Buschom [Sabz Pushan] pr. u. Schiras rarius,

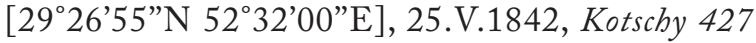
(G-BOIS [G00330405] !; isolecto-: E [E00327361] image seen, FI [FI009673] image seen, G [G00382756, G00382757, G00382758]!, GOET [GOET011067] image seen, K [K001096210] image seen, MO-97706 image seen, MO-97810 image seen, P [P03412070, $\mathrm{P} 03412071, \mathrm{P} 03412073$ in part., $\mathrm{P} 03412074]$ images seen, WAG [1835848], W [W0017712] image seen). Syntypi: Iran. Prov. Fars : Sabz Pushan [Sabst Buschom], 1842, Kotschy 843 (G-BOIS [G00330408]!, JE [JE00010888] image seen, $\mathrm{P}$ [P03412073] image seen, W [W0017422] image seen).

Perennial herb, 4-16 cm tall, decumbent, stems short, thin, numerous, with long internodes below and shorter above, grey, with a white dense indumentum of farinaceous hairs and with rare dispersed dendroid hairs. Lower leaves alternate, grey, densely farinaceous with a few dendroid branched hairs on both surfaces, petioles $8-20 \mathrm{~mm}$ long, blade broadly ovate in overall shape, $16-20 \times 5-10 \mathrm{~mm}$, venation pinnate, prominent on abaxial surface, pinnatifid to pinnatisect, upper part of leaf dentate, with 3-4 teeth 0.5-1 mm long each side; angle of teeth with reference to midrib $20-30^{\circ}$, subacute to obtuse; lower part of leaf divided, with 2-3 lobes 3-6 mm long each side, angle of lobes with reference to midrib $30-40^{\circ}$, obtuse, each lobe with ca. 2-3 teeth $0.5 \mathrm{~mm}$ long each side, angle of teeth ca. $45^{\circ}$, obtuse, apical side of tooth convex and straight, basal side of tooth concave. Upper leaves alternate, grey, densely farinaceous and with rare dendroid hairs on both surfaces, petiole 4$10 \mathrm{~mm}$ long, blade symmetrical, narrowly ovate, acute, $12-20$ $\times 4-7 \mathrm{~mm}$, venation pinnate, prominent on abaxial surface, blade pinnatifid to pinnatisect, with ca. 2-4 lobes each side; 

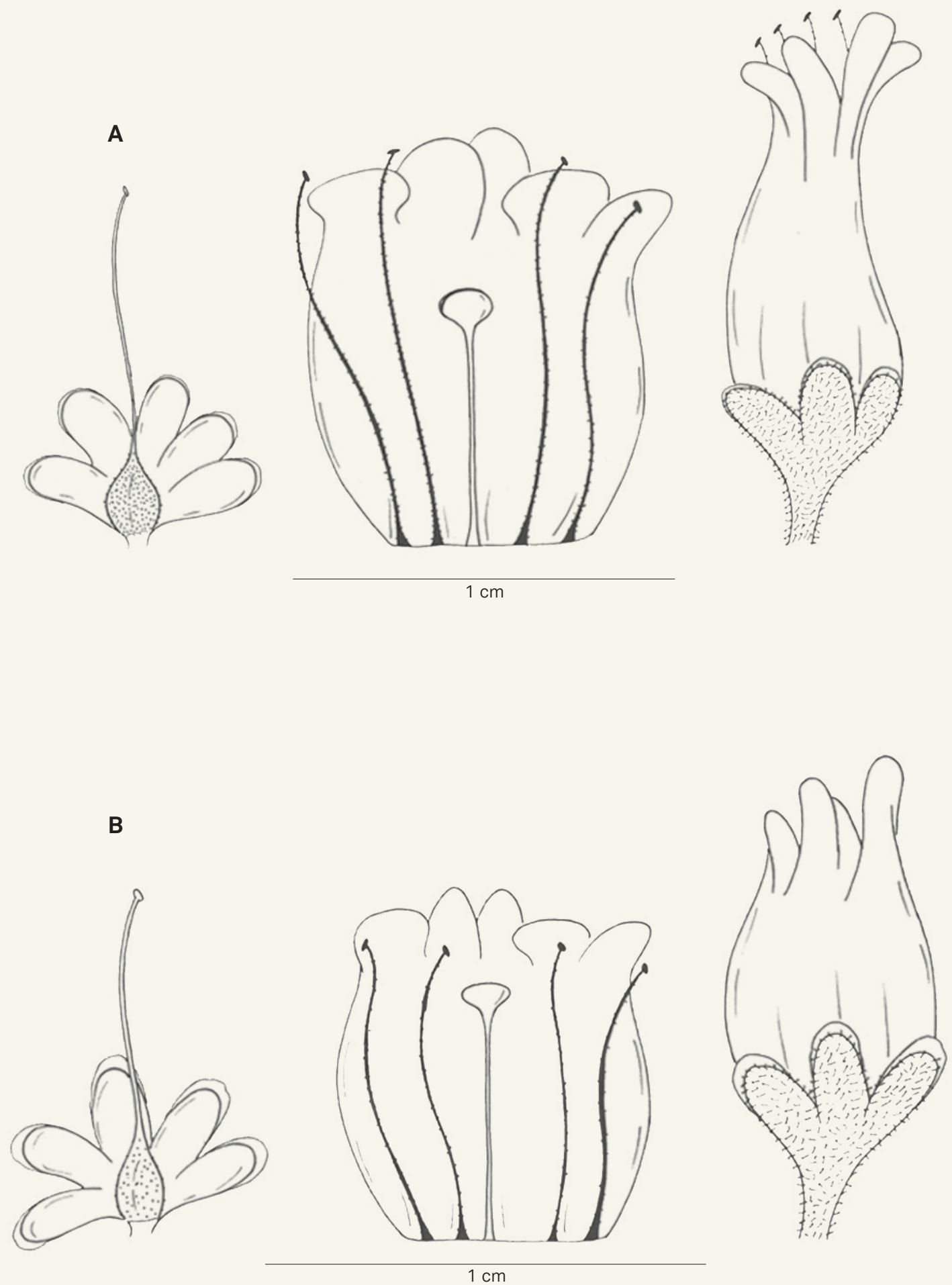

Fig. 1. - Flower structure. A. Scrophularia longiflora Benth.; B. Scrophularia nana Stiefelh. [A: Ranjbar 35993, BASU; B: Ranjbar 26927, BASU] 
A

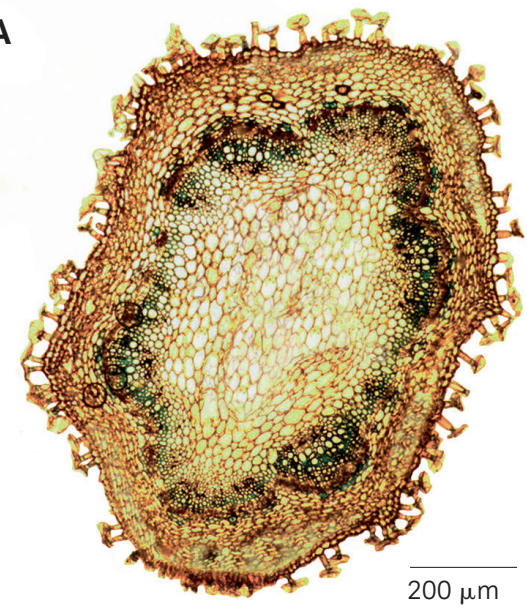

B

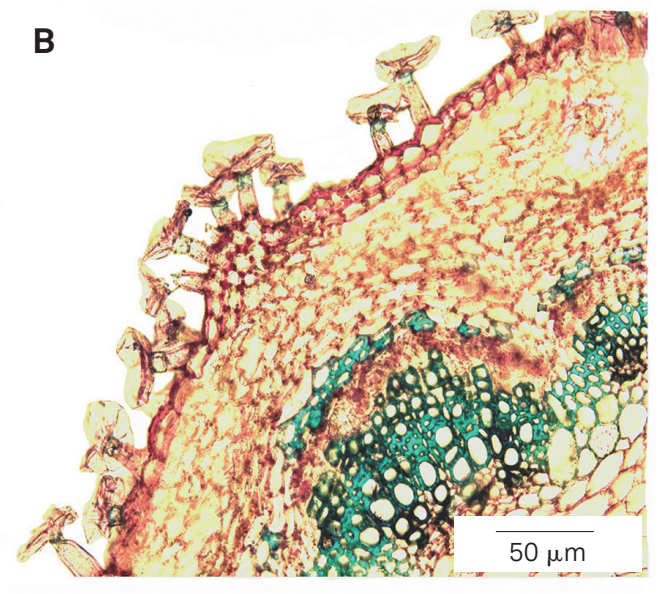

C

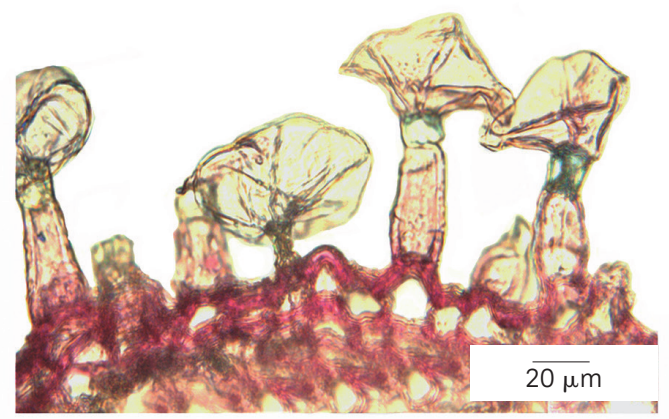

D

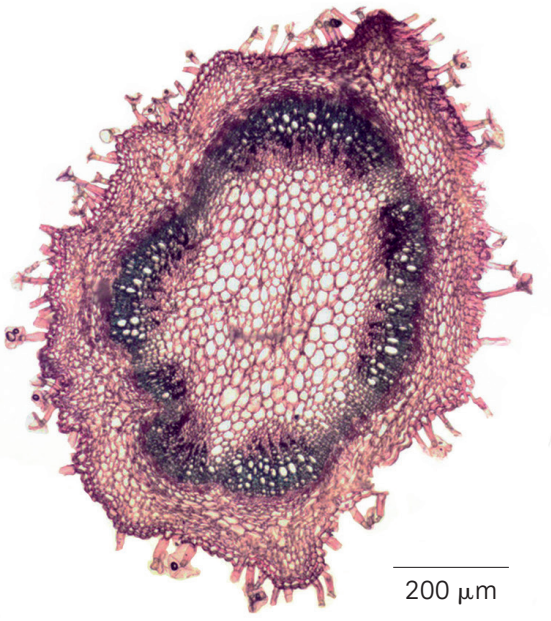

E

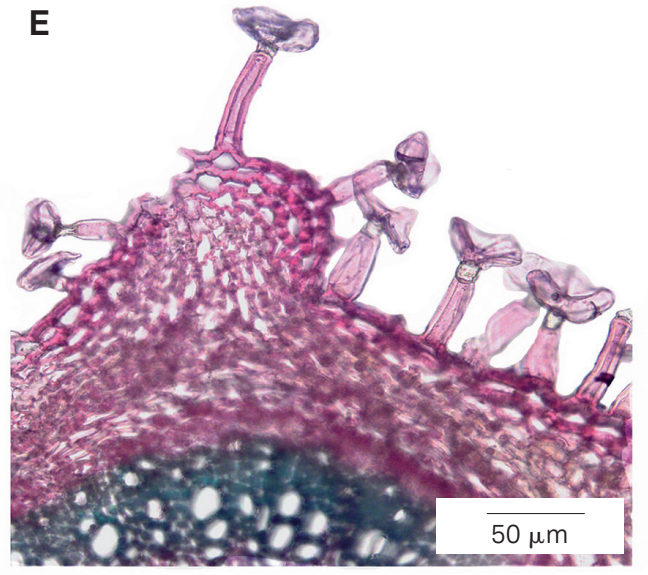

$\mathbf{F}$

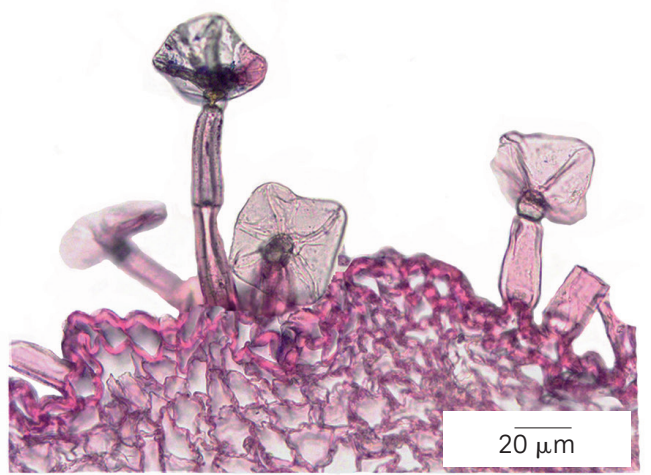

Fig. 2. - Anatomical comparison of stem transversal section of Scrophularia longiflora Benth. (A-C) and S. nana Stiefelh. (D-F).

A, D. Outline of the stem transversal section. B-C, E-F. Focus on farinaceous hairs at two different magnifications.

[A-C: Ranjbar 35993, BASU; D-F: Ranjbar 26927, BASU] 

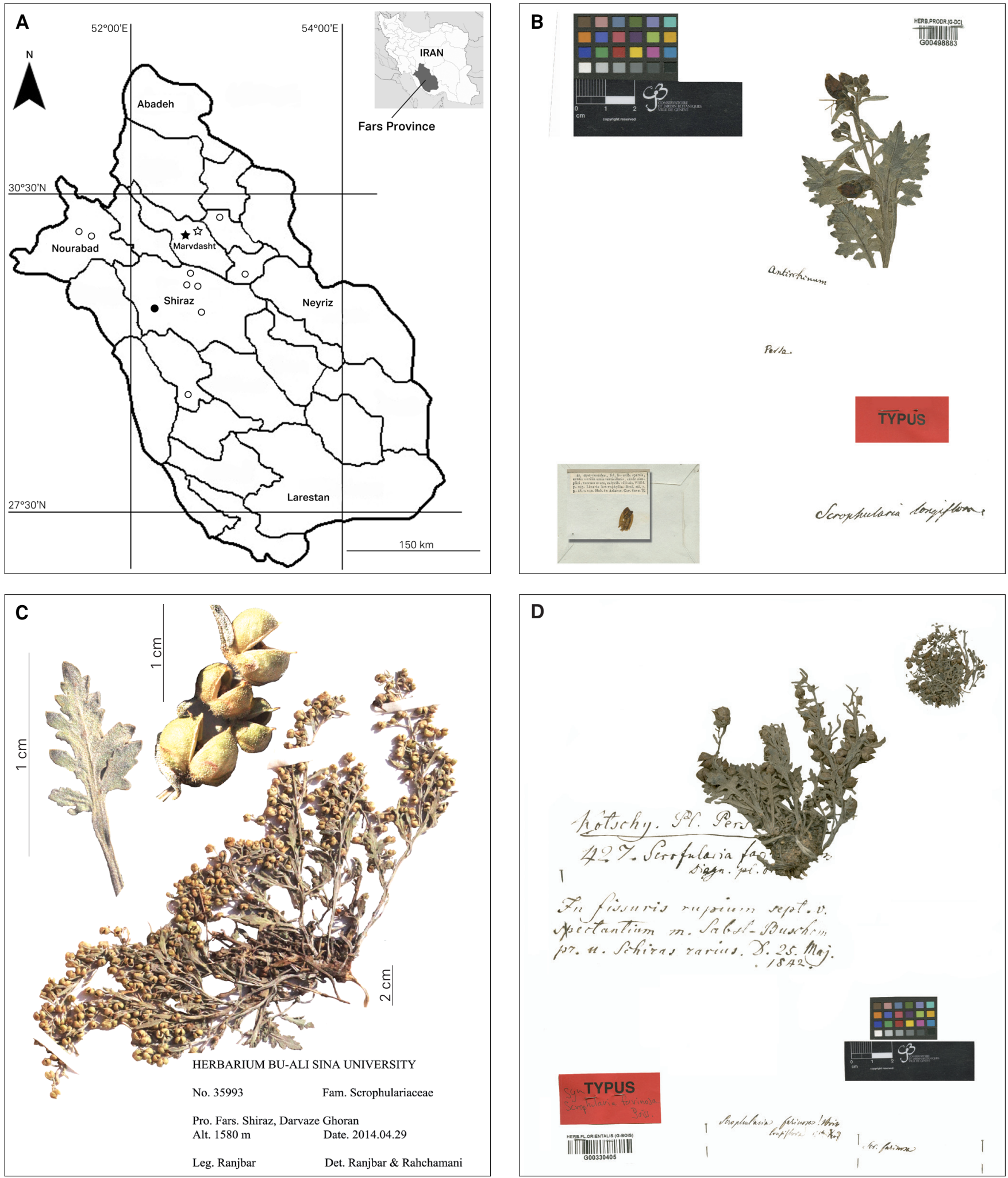

Fig. 3. - Distribution map of Scrophularia longiflora Benth. and S. nana Stiefelh. in Fars Province in Iran (A) and collections of S. Iongiflora (B-D). A. Examined specimens and data of "Flora Iranica" (white circles: S. Iongiflora; white stars: S. nana) and type collections (black circle:

S. farinosa (= S. longiflora); black star: S. nana); B. Holotype; C. Details of Ranjbar 35993 collection at BASU: overview of plant, close-up of leaf, and fruit; D. Lectotype of its synonym S. farinosa Boiss.

[B: Ranjbar 35993, BASU; C: Anon. s.n., G-DC; D: Kotschy 427, G-BOIS] 
0.5-1.8 mm long, angle of lobes with reference to midrib ca. $30^{\circ}$, acute, apical side of lobes convex to straight, basal side concave. Inflorescence dense, many-flowered, bracteate, paniculate, cymes drepanium, elongate in fruiting status up to 7-8 cm long. Bracts lanceolate, entire, acute, 5-10 × 1-3 mm, grey, densely farinaceous, the lower ones leaf-like. Bracteoles lanceolate, entire, acute, 3-3.5 × $1 \mathrm{~mm}$, grey, densely farinaceous. Peduncle 4-6 mm long, densely farinaceous hairs mixed with sparsely glandular hairs. Pedicels 1.5-2 mm long, densely glandular and with a sparsely farinaceous hairs. Flowers zygomorphic. Calyx 2.5-3 × ca. $2.5 \mathrm{~mm}$, sepals equal, ovate-orbicular, obtuse at apex, grey to greenish, densely covered with glandular hairs, with white often glabrous margins. Corolla 9-10 mm long, urceolate, yellow-white when fresh, brown in dried status, glabrous, lobes unequal, obtuse, upper lobes 1.5-2 mm longer than lower lobes. Stamens 4, fertile, exserted, 9.5-10 $\mathrm{mm}$ long, filaments white, densely glandular-dotted, anthers white. Staminode small, orbiculate, ca. $0.5 \times 0.5 \mathrm{~mm}$, purple, its filament shorter than the ones of the fertile anthers, and thus included in the corolla tube. Ovary spherical to ovoid, 1-1.5 $\times$ $1.5 \mathrm{~mm}$, densely gland-dotted. Style terminal, filiform, ca. $8 \mathrm{~mm}$ long, glabrous. Capsule spherical to ovoid, 3.5-5 × 3-4 mm, mucronate at apex, mucron 0.5-1 mm long, grey to green, densely gland-dotted. Seed rectangular to elliptic, 0.9-1.1 $\times 0.4-0.5 \mathrm{~mm}$, dark brown to black, with scattered depressed area, sometimes lighter discontinuous bands.

Notes. - The name $S$. longiflora was published on April 8, 1846 by Bentham (1846: 313) (see Stafleu \& Cowan, 1976), where it is clearly stated that the only specimen seen is a specimen of unknown collector coming from Persia, and kept in the de Candolle herbarium. There is only one specimen under this name in the G-DC herbarium, and this is consequently the holotype of that name.

The name $S$. farinosa first appeared in 1845 on the printed labels of Kotschy's specimen distributed and edited by R.F. Hohenacker. However, these labels lack any kind of diagnostic elements and hence the name cannot be considered as validly published until Boissier (1846), released in Jul.-Oct. 1846 according to Stafleu \& Cowan (1976). The species is described based on two collections: Kotschy 427 and 843 collected from Iran, Sabz Pushan (Sabst-Buschom) around Shiraz. Although Grau (1981) cites "Typus Kotschy 427, 843 ; holotypus G !, isotypus W!", the G-BOIS duplicates of these collections should be considered as syntypes and lectotypification is needed. The specimen Kotschy 427 [G00330405] is designed here as lectotype (Fig. 3D) because it is complete and includes a mature plant with fruit. The other specimen Kotschy 843 [G00330408] is not complete being without fruit. Besides, Kotschy 427 is much more widely distributed in other herbaria.
Both Boissier (1879) and Grau (1981) have correctly considered that $S$. farinosa and $S$. longiflora were synonyms. However, they both retained the name $S$. farinosa, whereas $S$. longiflora was effectively published a few months earlier and has priority.

Other specimens examined. - Iran. Prov. Fars: Sabz Pushan [Sabst Buschom], 1842, Kotschy 427a (G [G00330574]); sine loc., s.d., Michaux s.n. (G [G00382553]); around Shiraz, s.d., Michaux s.n. (P [P03412072]); Shiraz, Darvaz-e Qoran, 2938'03”N 52³3’37”E, 1580 m, 29.IV.2014, Ranjbar 35993 (BASU); Bamu protected region, Darreh Chap, 1650-1900 m, 30.V.1975, Wendelbo E Foroughi 17531, partly (G [G00418106]).

Scrophularia nana Stiefelh., Bot. Jahrb. Syst. 44: 479. 1910. (Fig. 4A, B)

Lectoypus (designated here) : Iran. Prov. Fars: around Persepolis and Kotel Parrou, Haussknecht s.n. (JE [JE00010886] image seen; probable isolecto-: G [G00330575]!, W [W0017409] image seen).

Perennial herb, 3-15 cm tall, erect, stems short, thin, branched, with long internodes below and shorter above, grey, with a white dense indumentum of farinaceous hairs. Lower leaves opposite, grey, densely farinaceous on both surfaces, petioles 5-12 mm long, blade broadly ovate to rhombic to deltoid, $15-20 \times 10-17 \mathrm{~mm}$, venation pinnate versus palmate, serrate to dentate, with ca. 6-8 teeth each side; 1-3 mm long, angle of teeth with reference to the midrib ca. $40^{\circ}$, obtuse, apical side of teeth convex and straight, basal side concave. Upper leaves opposite to rarely alternate, grey, with densely farinaceous hairs on both surfaces, petiole 5-8 mm long, blade broadly ovate to rhombic, obtuse, $18-20 \times 10-14 \mathrm{~mm}$, venation pinnate, serrate to dentate, with ca. 5-7 teeth each side; $0.5-2 \mathrm{~mm}$ long, angle of teeth with reference to the midrib ca. $30^{\circ}-40^{\circ}$, obtuse, apical side of teeth convex to straight, basal side concave. Inflorescence 4-5 cm long, dense, many-flowered, bracteate, paniculate, cymes drepanium. Bracts lanceolate, entire, acute, 10-15 × 2-5 mm, grey, with a dense indumentum of farinaceous hairs, the lower ones with a few teeth. Bracteoles lanceolate, entire, acute, $2-3 \times 0.5 \mathrm{~mm}$, grey, with a dense indumentum of farinaceous hairs. Peduncle 5-10 mm long, densely glandular mixed with sparsely farinaceous hairs. Pedicel 1-1.5 mm long, with densely glandular hairs. Flowers zygomorphic. Calyx 3-4 × 2.5-3 mm, sepals equal, ovate-elliptic, obtuse, grey, with white often glabrous margins, densely covered with glandular hairs. Corolla 5-7 mm long, ventricose, purple when fresh, red to brown in dried status, glabrous, lobes unequal, obtuse, upper lobes $0.5 \mathrm{~mm}$ longer than lower lobes. Stamens 4, fertile, included, 5-7 mm long, filaments white, loosely gland-dotted, anthers white. Staminode small, reniform, ca. $0.5 \times 1 \mathrm{~mm}$, red, its filament as long as the ones of the fertile anthers. Ovary spherical, ca. $1.5 \times 2 \mathrm{~mm}$, loosely gland-dotted. Style terminal, filiform, 4-5 mm long, glabrous. Capsule spherical to ovoid, ca. $3 \times$ $3.5 \mathrm{~mm}$, mucronate, mucrone $0.5 \mathrm{~mm}$ long, green, loosely glanddotted. Seed elliptic, to $1 \mathrm{~mm}$, brown. 

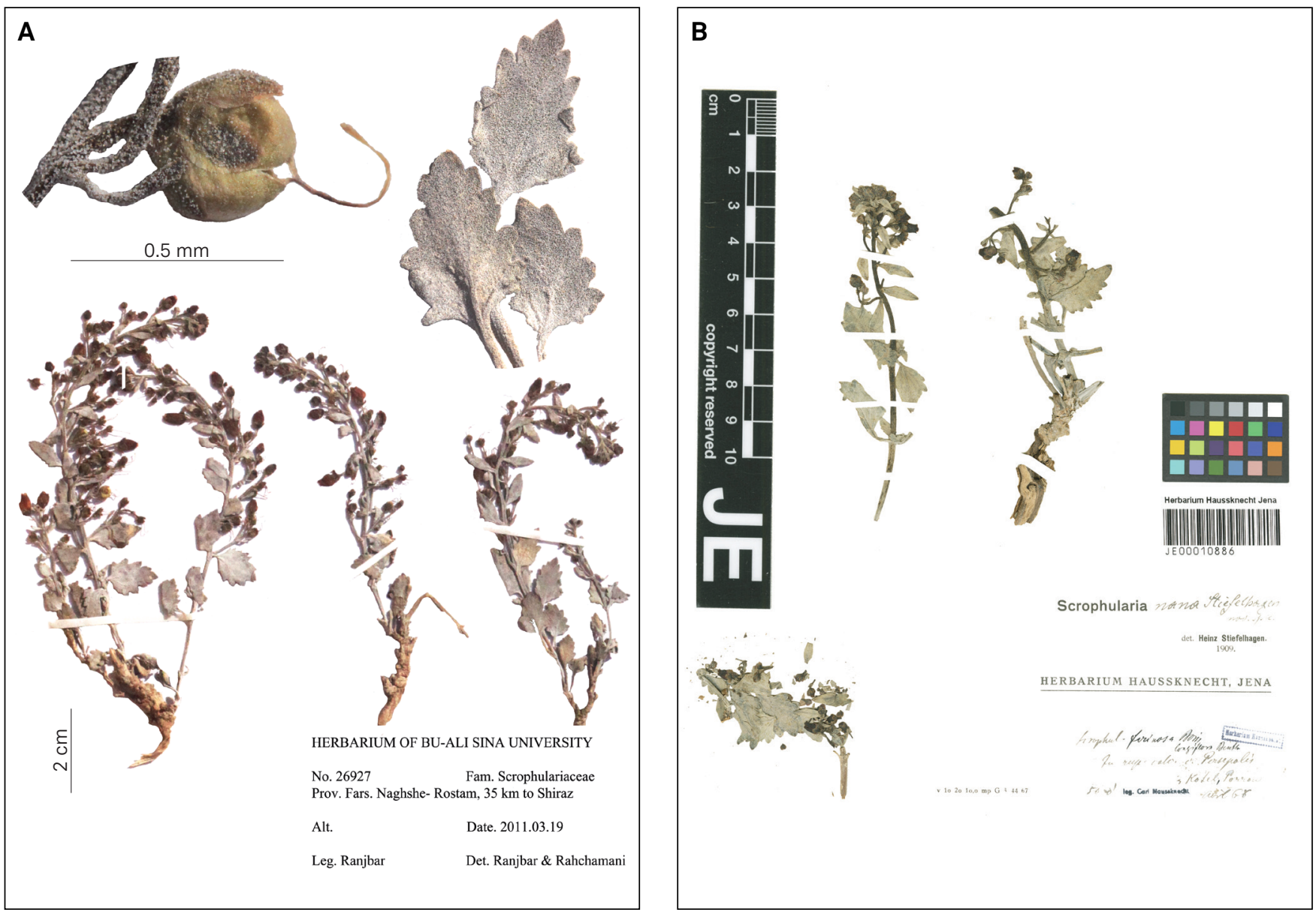

Fig. 4. - Scrophularia nana Stiefelh. A. Details of Ranjbar 26927 collection at BASU: overview of plant, close-up of leaf, and fruit; B. Lectotype.

[A: Ranjbar 26927, BASU; B: Haussknecht s.n., JE]

Note. - The protologue of $S$. nana provides the following indications: "Verbr.: Südwestliches Persien: Kalkfelsen bei Persepolis und Kotel Parrou, 5000’ (leg. Hausskn. April 1868 sub S. farinosa Boiss.)". However, there is no mention of the herbarium of deposition of the type and lectotypification is needed. Among herbaria where corresponding material has been traced, herbarium JE, where the Haussknecht herbarium is now incorporated, has two specimens by Haussknecht that were recently databased as syntypes. Both have an identification label by Stiefelhagen as "Scrophularia nana Stiefelhagen nov. spec.; det. Heinz Stiefelhagen. 1909”. However, only one of them [JE00010886] has a locality ("In rup. calc. ca. Persepolis et Kotel Parrou; 5000") that matches the protologue. Consequently, this specimen has been selected as lectotype. The second specimen, [JE00010885], with locality "In rup. calc. ca. Persepolis et Kotel Kumaredj", is not cited in the diagnosis and despite its label by Stiefelhagen, it should not be considered as type material. Duplicates of these collections in other herbaria have either a locality with elements of these two collections [G00330575] or a locality which is too vague to be attributed to one of these collections [W0017409]. Both should be considered as probable isolectotypes.

In the diagnosis of this species a wide variation of leaf shape is mentioned. Among all observed specimens, margin leaf is irregular crenate, serrate to dentate or incised, but never pinnatipartite. This character is very important and a distinguishing trait between $S$. nana and S. longiflora. Another point is that the fruit of this species was not described. Based on examined specimens and digital images, we provide above a description of capsules and seeds.

Other specimen examined. - Iran. Prov. Fars: Marvdasht, Naqshi Rostam, 29 59'19”'N 52 52'29”'E, 1644 m, 19.III.2011, Ranjbar 26927 (BASU); Takht-e Jamshid [Persepolis] and Kotel Kumaredj, 1525 m, IV.1868, Haussknecht s.n. (JE [JE00010885]); between Takht-e Jamshid [Persepolis] to Daulatabad [Dolat Abad], 1000-2000 m, 2.V.1956, Schmid 5471 (G [G00382551]); Bamu protected region, Darreh Chap, 1650-1900 m, 30.V.1975, Wendelbo \& Foroughi 17531 (G [G00382552 in part]). 


\section{Acknowledgments}

We would like to thank Dr. Attar (Prof. of Plant Systematics - Tehran University) for her suggestions and guidance as the pioneer researcher of the genus Scrophularia in Iran. We are indebted to the personnel of the following herbaria: BM, G, $\mathrm{JE}, \mathrm{K}, \mathrm{MO}, \mathrm{P}$, TUH and $\mathrm{W}$ for their contribution during the revision of materials and for providing type images. The field work in Iran was supported by grants from Bu-Ali Sina University. We would also like to thank two anonymous reviewers for their helpful comments.

\section{References}

Attar, F. (2011). Scrophulariaceae In: Assadi, M. (ed.), Fl. Iran 68: 206-307. Research Institute of Forests and Rangelands, Tehran.

Bentham, G. (1846). Scrophulariaceae. In : Candolle, A.P. de \& A. de Candolle (ed.), Prodr. $10: 180-586$.

Boissier, P.E. (1846). Diagn. Pl. Orient. ser. 1, 7.

Boissier, P.E. (1879). Scrophularia. Fl. Orientalis 4: 387-421.

Grau, J. (1981). Scrophulariaceae. In: Rechinger, K.H. (ed.), Fl. Iranica 147: 213-284. Akademische Druck- und Verlagsanstalt.

Mabberley, D.J. (1997). The plant book. Cambridge University Press.

Scheunert, A. \& G. Heubl (2011). Phylogenetic relationships among New World Scrophularia L. (Scrophulariaceae) : new insights inferred from DNA sequence data. Plant Syst. Evol. 291: 69-89.

Stafleu, F.A. \& R.S. Cowan (1976). Taxonomic Literature. Vol. 1. $2^{\text {nd }}$ ed. Scheltema, Bohn \& Holkema.

Stiefelhagen, H. (1910). Systematische und pflanzengeographische Studien zur Kenntnis der Gattung Scrophularia. Bot. Jahrb. Syst. 44: 406-496.

Willis, J.C. (1973). A dictionary of the flowering plants and ferns. $8^{\text {th }}$ ed. University Press, Cambridge. 